\title{
PERAHU-PERAHU MASA KLASIK, BUKTI KEJAYAAN NEGERI BAHARI INDONESIA
}

\author{
T.M. Hari Lelono \\ (Balai Arkeologi Yogyakarta)
}

\begin{abstract}
The Honor of our Nation is often tested by our neighbouring countries with some provocative actions. Since the ancient period of Majapahit Kingdom which was also well-known as a maritime kingdom, Gajah Mada had succeeded in uniting the Nusantara (the Nation) through his strong military navy. It's neither a myth nor a slogan because it has been proven archaeologically by the ships reliefs sculptured on the wall of the Borobudur Temple dated back to 200 years ago. Other evidence is on the inscriptions of Kediri and Majapahit which mentioned about ships, fishermen, captain and the process of building a ship. The spirit as well as the intelligence of our ancestors must be appreciated and honored as a real breath and spirit of our own, presenting an identity and dignity of one Nation. This pride will be the most precious base maintain the unition of Negara Kesatuan Republik Indonesia.
\end{abstract}

Key words: negeri bahari, arkeologi, artefak, jatidiri

\section{PENDAHULUAN}

Jawa Tengah telah berkembang menjadi pusat budaya Masa Klasik sekitar abad VII - X Masehi. Budaya yang dilatari oleh adanya pengaruh anasir-anasir India itu telah mencapai perkembangan yang pesat di wilayah ini. Berbagai aspek kehidupan telah dipengaruhi oleh budaya dari India yang dilatarbelakangi oleh dua agama besar pada masa itu, yaitu Hindu dan Buddha (Tjahjono, 2008: 6). Tinggalan budaya yang monumental masih dapat disaksikan hingga kini terutama berupa bangunan candi-candi, di antaranya Candi Borobudur, Mendut, Gunung Wukir, Asu, Lorojonggrang, Sewu, dan masih banyak lagi candi lainnya. Pengaruh kebudayaan India tersebut, kemudian hijrah ke Jawa Timur bersamaan dengan pindahnya kerajaan Mataram Hindu oleh beberapa sebab, seperti bencana alam dan situasi politik. $\mathrm{Di}$ tempat yang baru-pun kebudayaan tersebut dapat berkembang dengan pesat dan mencapai masa puncaknya pada masa Kerajaan Majapahit.

Majapahit sebagai kerajaan besar, dapat menguasai wilayah Nusantara dengan kekuatan militer yang dimiliki di bawah pimpinan panglima perang (mahamantri) Gajahmada. Dalam mewujudkan cita-citanya 
untuk mempersatukan Nusantara, armada Majapahit dikirim untuk menaklukkan Palembang, menghancurkan Tumasik (yang sekarang dikenal sebagai Singapura), dan menguasai perairan di perbatasan Laut Jawa dan Selat Makasar, Sukadana, Banjarmasin, Kutei, Maluku dan sekitamya (Dulaurier, 1846; Slametmuljana, 1979; Koestara, 1997: 68 - 69). Penaklukan demi penaklukan antarpulau memerlukan armada dengan perahu yang kuat untuk mengarungi samudra luas dan mampu mengangkut tentara sebanyak mungkin. Perahu-perahu tersebut, tentu dibuat tidak terlalu jauh dari pusat pemerintahan. Sebagaimana diketahui, daerah pesisir utara Jawa berperan penting dalam penyiapan dan pengadaan prasarana, sarana serta fasilitas lain untuk lalu lintas air. Adanya dua sungai besar Bengawan Solo dan Kali Brantas yang bermuara di pantai utara Jawa Timur dimanfaatkan untuk menghubungkan daerah pedalaman, khususnya ke Ibukota Majapahit, dengan daerah pesisiran. Selain itu, sungai-sungai itu digunakan pula untuk lalu lintas perdagangan, militer dan kepentingan lainnya.

Sementara itu, daerah pesisir telah berkembang menjadi pos-pos persinggahan atau pelabuhan bagi jaringan pelayaran antarpulau. Ramainya lalu-lintas pelayaran dan perdagangan telah menjadikan daerah pantai utara semakin cepat berkembang. Daerah yang semula merupakan pos-pos kecil, lama-kelamaan berkembang menjadi kota-kota pantai dengan dermaga-dermaga besar, sehingga mampu disinggahi kapal-kapal asing (antarpulau). Sebagai daerah perdagangan dan persinggahan perahu-perahu antarpulau dan antarnegara, tentunya di kota-kota itu terjadi pula kontak budaya antaretnis yang datang untuk melakukan transaksi perdagangan atau kepentingan lainnya. Terjadinya kontak dan interaksi yang dilakukan terus-menerus tersebut, akhirnya dapat memperkaya budaya lokal masyarakat pesisiran.

Ramainya lalu lintas perdagangan antarbangsa yang menyinggahi pantai utara Jawa, memberikan kontribusi dalam sektor ekonomi dan menjadi sumber pendapatan utama kota-kota pelabuhan di daerah pesisir. Aktivitas pelayaran dan perdagangan tersebut menyiratkan adanya bermacam jenis dan ukuran perahu yang singgah di dermaga-dermaga pelabuhan untuk melakukan proses bongkar-muat barang kebutuhan dan komoditi masyarakat Majapahit pada masa itu. Diduga di sekitar daerah pelabuhan atau dermaga, terdapat bengkelbengkel tempat perbaikan maupun pembuatan perahu yang dilakukan oleh penduduk yang tinggal di daerah

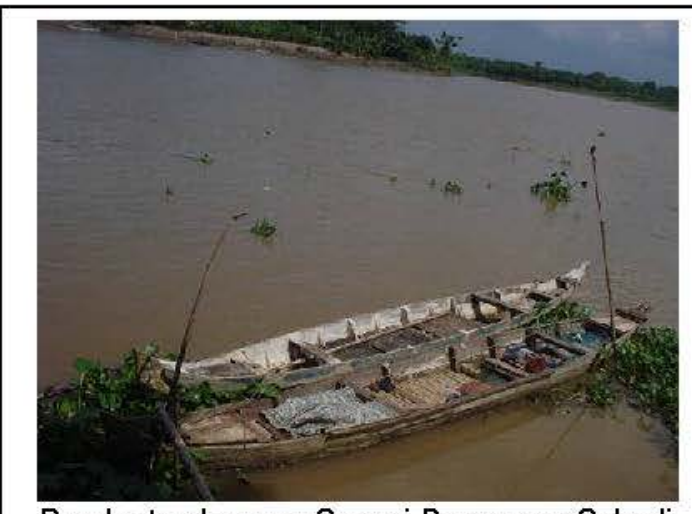

Perahu tambangan Sungai Bengawan Solo di daerah Mojopura, Gresik 
sekitarnya.

Perahu sebagai alat transportasi, berdasarkan pada jenisnya dapat dibedakan sekurangnya ada dua jenis. Perahu yang digunakan untuk pelayaran sungai, bentuk dan ukurannya berbeda dengan yang digunakan untuk mengarungi samudera. Perahu untuk laut, bentuk dan ukurannyapun juga dapat dibedakan berdasarkan pada jarak yang akan dtempuh. Bentuk perahu untuk pelayaran antara pulau-pulau yang dekat, tentu berbeda dengan bentuk perahu untuk mengarungi samudra luas dengan gelombang besar yang biasanya terjadi dalam pelayaran jarak jauh atau antarnegara. Umumnya perahu yang digunakan di laut, bentuk haluannya lebih tinggi dibandingkan dengan yang di sungai. Haluan tinggi berfungsi sebagai penahan gelombang. Dari segi ukurannya, perahu sungai lebih kecil dan ramping, terutama di Jawa yang sungai-sungainya tidak terlalu lebar seperti di Pulau Sumatera dan Kalimantan. Perbedaan lainnya terletak pada penggerak perahu. Perahu layar biasanya digunakan di laut. Ukuran layar dan banyak tiang layar, akan tergantung pada ukuran perahu-nya. Sementara itu, perahu sungai biasanya lebih banyak menggunakan dayung atau galah dari bambu untuk mendorong gerak perahu. Perahu jenis ini dapat dijumpai pada penyeberangan sungai tradisional atau penambangan (tambangan)

Hampir pasti teknologi pembuatan perahu sudah dikuasai sejak jaman dulu oleh penduduk Pulau Jawa, baik yang ada di daerah pesisir pantai utara maupun yang ada di pedalaman, khususnya yang tinggal di tepi Sungai Bengawan Solo dan Kali Brantas. Mereka tentu juga sudah memiliki perahu untuk melakukan pelayaran dan perdagangan. Jenis perahu apa saja yang dikenal dan dipakai pada masa Jawa Kuna belum banyak diketahui. Namun berdasar pada sumber prasasti dapat dirunut beberapa jenis perahu yang digunakan penduduk Majapahit pada waktu itu.

Nenek moyang Indonesia, sebagai bangsa yang berbudaya tinggi telah menunjukkan jatidirinya dalam dunia bahari, dan telah menguasai lautan sampai ke negera-negara tetangga dengan perahu-perahu layar mengarungi samudera. Beberapa jenis perahu yang digunakan pada masa lalu telah dapat dikenali, tetapi bagaimana teknologi pembuatan dan kehidupan nelayan pada masa itu belum diketahui. Oleh karena itu, permasalahan yang ingin diketahui adalah: Bagaimana kehidupan nelayan dan teknologi pembuatan perahu? Untuk menjawab permasalahan tersebut akan diacu, tentang kehidupan nelayan di Pesisir Utara Jawa Timur, dan muara sungai-sungai sebagai bahan analogi.

\section{PERAHU DALAM PRASASTI DAN RELIEF}

Gambaran bentuk perahu pada beberapa relief yang ada di Candi Borobudur telah memperkuat asumsi bahwa Jawa pada masa Mataram Hindu telah mengenal dan menggunakan perahu untuk kepentingan pelayaran. Hal tersebut telah menunjukkan citra Indonesia sebagai negeri 
bahari. Beberapa bukti lain yang tidak kalah penting adalah informasi tentang perahu dalam beberapa prasasti yang ditemukan di daerah Sumatera dan Jawa. Memang, tidak banyak prasasti yang memuat tentang ciri kebaharian, tetapi beberapa yang ditemukan di Jawa maupun di Sumatera, justru semakin memperkokoh jatidiri Indonesia, sebagai negeri maritim yang kuat dan disegani. Prasasti yang umumnya ditulis pada media dari batu andesit atau lempengan logam (tembaga dan perunggu), khususnya yang ditemukan di Jawa, telah dibaca oleh ahli epigrafi di antaranya JLA Brandes, NJ Krom (1913), WF Stutterheim (1934), Sutjipto (1958), T.G. Pigeaud (1960), Himansu Bhusan Sarkar (1972), L.Ch. Damais, dan M.M. Soekarto Karto Atmodjo (1979).

Rita Margaretta (1993), mengungkapkan ada beberapa prasasti Jawa kuna menyebutkan hal-hal yang terkait dengan perahu. Ada prasasti yang menyebut beberapa jenis perahu, pembuat perahu, maupun aktivitas pelayaran melalui sungai. Diketahui pula bahwa, untuk mencapai pusat Kerajaan Majapahit yang pusat pemerintahannya terletak di pedalaman (daerah Trowulan, Mojokerto), dapat ditempuh melalui jalan darat atau jalur sungai. Melalui jalur darat digunakan kuda dan gerobak untuk mengangkut barang, sedangkan di jalur sungai menggunakan perahu, melalui Kali Brantas dan Bengawan Solo. Jalur sungai tersebut, diduga memang tidak bisa langsung menuju ibukota, tetapi perjalanan dilanjutkan melalui darat. Kepastian tentang hal ini memang perlu ditelaah lebih lanjut. Kedua sungai ini bermuara di pantai utara pulau Jawa, di daerah antara Surabaya (Bangil) dan Gresik. Sayang, beberapa prasasti tersebut lokasi penemuannya tidak diketahui, tetapi setidaknya dari nama tokoh/ raja yang disebutkan memerintah ketika prasasti diterbitkan dapat diketahui pertanggalannya. Isi beberapa prasasti tersebut secara umum menginformasikan tentang perdagangan dengan menggunakan perahu, sebagai salah satu alat transportasi. Selain itu adapula yang berisikan keterangan jenis perahu yang digunakan untuk suatu kegiatan/ aktivitas perdagangan atau ritual. Beberapa prasasti yang secara khusus menulis tentang penggunaan perahu, diantaranya adalah sebagai berikut.

1. Prasasti Ayam Těas I

Tempat Temuan

Angka Tahun

Nama Raja

Keterangan

Isi

Acuan
Purworejo, Jawa Tengah

822 Ç/ 1 Janari $901 \mathrm{M}$

Cri Mahārāja Rakai Watukura Dyah Dharmodaya Mahasambu

terpahat di atas lempengan tembaga berukuran $25 \mathrm{~cm} \times 9 \mathrm{~cm}, 9$

baris di bagian depan dan 6 baris di bagian belakang dengan menggunakan huruf dan bahasa Jawa Kuna.

peresmian Desa Ayam Teas menjadi daerah perdikan (sima)

WF Stutterheim (1938; 121 - 122). 
Bagian kunci

Terjemahannya

\section{Prasasti Telang}

Tempat Temuan

Angka Tahun

Nama Raja

Keterangan

Isi

Acuan

Kutipan

Terjemahannya

.."hana ayam těas atapa amasunghara 3 saparahu kabua maku ngalana tundan..."

..." semuanya dibawa dengan tiga perahu yang menggunakan gandengan (semacam tug boat)..."

tepi Sungai Bengawan Solo dekat Wonogiri, Jawa Tengah

825 C / 903 M

Çri Mahārāja Rakai Watukura Dyah Balitung

Çri Dharmodaya Mahāsambhu

berhuruf dan berbahasa Jawa Kuna.

Maharaja Balitung melaksanakan kaul dari raja yang dimakamkan di Satassrengga untuk membuat pangkalan di tepi Sungai Solo sebagai tempat tambangan bagi perahu yang menghubungkan kedua tepinya, menaikkan dan menurunkan barang serta penumpang. Penyeberangan tersebut tanpa dipungut biaya. Karena itu, Desa Telang, Mahe dan Paparahuan dijadikan sima.

WF Stutterheim (1934: 275), Himansu Bhusan Sarkar (1972)

..." umentassakna sang mahāwan pratidina..."

..." menyeberangkan orang dilakukan tiap hari ..."

3. Prasasti Kamalagyan/Kelagen,

Tempat Temuan

Angka Tahun

Nama Raja

Keterangan

Isi

Acuan

Kutipan
Tidak diketahui 959 Ç/ $1037 \mathrm{M}$

Airlangga

berhuruf dan berbahasa Jawa Kuna yang dipahatkan pada batu andesit.

Pembangunan bendungan untuk menghindari banjir di Waringin Sapta oleh Airlangga sekaligus penetapan desa Kamalagyan sebagai perdikan dengan tugas menjaga dan memelihara bendungan tersebut.

JLA Brandes - Krom (1913: 135) dan Sutjipto (1958)

"... tkang banawan amatiú hilinyanlor kapwata sukhamanah ikang maparahu 
Terjemahannya

samanghulu manalap bhanda $r i$ hujung galuh..."

"... aliran sungai ke arah utara dan semuanya senang berperahu mengambil barang-barang di Hujung Galuh..."

4. Prasasti Ferry

Tempat Temuan

Angka Tahun

Nama Raja

Keterangan

Isi

Acuan

Kutipan

Terjemahannya

\section{Prasasti tanpa nama}

Tempat Temuan

Angka Tahun

Nama Raja

Keterangan

Isi

Acuan

Kutipan
Dukuh Pelem, Desa Temon, Kecamatan Trowulan, Mojokerto, Jawa Timur.

1280 Ç/ $1358 \mathrm{M}$

Dyah Çri Hayam Wuruk

Terpahat di atas lima lempengan tembaga, berhuruf dan berbahasa Jawa Kuna

Daftar nama-nama desa di seluruh Pulau Jawa yang mendapat kewajiban untuk menyeberangkan penduduk dan memperlancar perdagangan.

T.G. Pigeaud (1960: 110). M.M. Soekarto Karto Atmodjo (1979: $70-72$ )

"... kapangkwa denikang anāmbangi sayawadwipamandala. makā nusa, i tëmon..."

"... i kĕmbu, i wulayu, sanwwe, ika tā kābeh nadthrapradeça.

Sthānanya ng anāmbangi sayawa-dwīpa..."

"... supaya disimpan oleh semua petugas penambangan di seluruh Pulau Jawa, nusa temon..."

"... kembu, wulayu, itulah semua desa-desa

di tepi sungai, tempat penambangan atau peyeberangan di seluruh pulau..."

tidak diketahui

tidak ada

tidak ada

ditulis di atas lempengan tembaga dengan menggunakan huruf dan bahasa Jawa Kuna.

menyebutkan nama Wimalacrama dan beberapa jenis perahu.

JLA Brandes (1913: 245)

..."parahu panawa kalima tundan, parahu pakbowan sawiji kapat tundan, parahu jurag 5, parahu panggagaran 5, parahu pawalijan 5 , parahu pangngayan 5..." 
.." perahu panawa dengan 5 gandengan, satu perahu untuk mengangkut hasil kebun dengan 4 gandengan perahu jurag 5 , perahu panggaran 5 , perahu pedagang 5 , perahu panggayan 5 ..."

Secara garis besar terdapat dua prasasti yang menyebut tentang jenis perahu yang menggunakan gandengan di belakangnya. Disebutkan ada lima jenis perahu yang digunakan antara lain: perahu panawa, perahu jurag, perahu panggaran, perahu dagang dan perahu panggayan. Perahu dagang tentunya jenis perahu yang cukup besar, karena selain memuat barang juga untuk memuat manusia. Sementara itu, tiga prasasti lainnya menyebutkan tentang aktivitas pelayaran dan penyeberangan sungai.

Prasasti Kamalagyan/Kelagen yang diterbitkan pada masa Airlangga juga menyebut tentang perahu di sungai. Diduga sungai yang dimaksud dalam prasasti tersebut adalah Sungai Brantas, karena sungai ini relatif lebar, dalam, berarus sedang, dan bermuara di daerah Bangil/ Surabaya. Apalagi dalam prasasti itu ditulis aliran sungai ke utara dan menuju Hujung Galuh. Uraian itu sesuai sekali dengan keadaan Sungai Brantas yang mengalir ke Laut Jawa dan berhulu di pedalaman sekitar Kediri.

Dalam bait yang lain ditulis: (12)... Kapwa ta sukha manah nikan maparahu samanhulu manalap bhānda $i$ hujun galuh tka (13) rikan para puhawan para banyāga sanka rin dwipāntara (=semua senang hatinya, orang-orang yang berperahu ke hulu untuk mengambil barang dagangan di Hujung Galuh (mereka yang datang ke sana (ialah) para nakoda (dan) para pedagang dari pulaupulau lain (Nastiti, 2003: 49). Tulisan tersebut semakin jelas memberikan gambaran tentang penggunaan perahu melalui jalur-jalur sungai dalam lalu-lintas

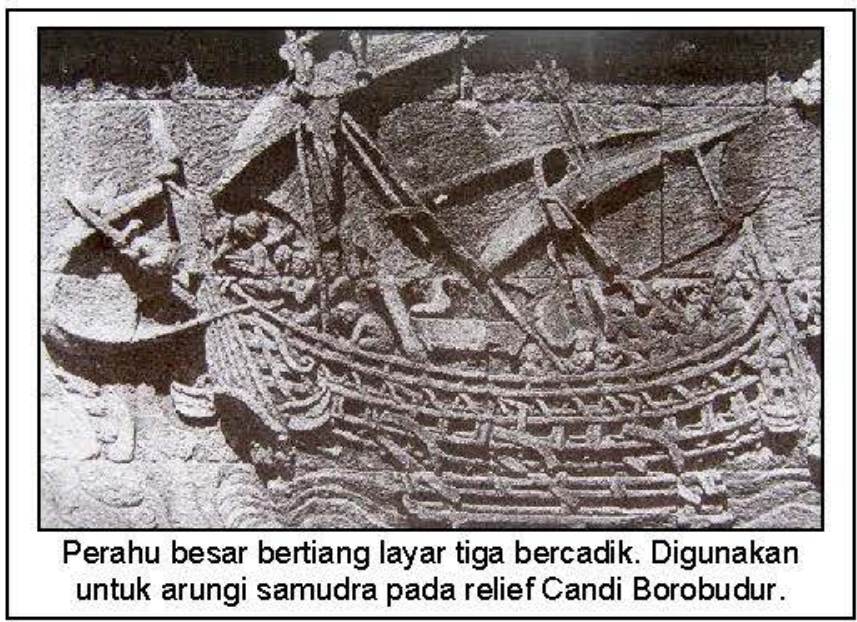
perdagangan.

Selain sumber-sumber prasasti tersebut di depan, pada abad VIII M digambarkan peran penting perahu sebagai alat transportasi yang dapat dibedakan bentuk, ukuran, dan jenis berdasarkan fungsinya. Relief yang dipahatkan pada dinding Candi Borobudur memberikan bukti kuat, tentang peran perahu pada masa Klasik. Perahu dengan tiga layar merupakan salah satu bentuk perahu besar dapat digunakan untuk mengarungi samudra. Perahu-perahu layar dipergunakan pada jalur perdagangan antara 
Indonesia dan India. Tentu saja ukuran lebih besar, karena harus dapat memuat barang dagangan sampai ratusan ton dengan sekitar dua ratus penumpang. Perahu menggunakan layar, biasanya untuk berlayar selalu memanfaatkan angin dan musim yang ada, yakni musim angin barat atau musim angin timur. Hal tersebut tergantung dari tujuan pelayaran yang akan ditempuh. Pada relief yang lain digambarkan perahu berukuran lebih kecil tanpa layar dan digerakan dengan dayung atau galah. Mungkin perahu ini dipakai sebagai perahu sungai atau hanya di pantai.

\section{PERAN PERAHU PADA MASA KLASIK}

Indonesia merupakan negeri kepulauan yang letaknya sangat strategis, di antara Benua Asia dan Australia, sehingga berkembang jalur lalu-lintas pelayaran, perdagangan, dan menjadi persinggahan kapal-kapal asing untuk melakukan perbaikan dan menambah bahan makanan. Karena posisinya yang strategis, muncul dermaga-dermaga di sepanjang pantai utara Jawa. Berdasarkan bukti arkeologis dan naskah kuna, antara lain Nagarakretagama dan Pararaton, dapat digambarkan daerah pantai yang ramai sebagai tempat persinggahan perahu mancanegara. Konsekuensinya, daerah pantai berkembang pesat sebagai pelabuhan dan tempat berinteraksinya antara para pedagang mancanegara. Ketika masa Kerajaan Majapahit perkembangan itu pun terjadi, walaupun letak pusat pemerintahan jauh berada di daerah pedalaman. Daerah pesisir, sebagai wilayah kekuasaannya, berperan penting dalam aktivitas pelayaran antarpulau maupun negara, baik untuk kepentingan ekonomi maupun militer. Kapal dan perahu tentu amat dibutuhkan untuk mengangkut armada perang ketika menaklukkan daerah lain.

Sri Suyatmi Satari dalam Haris Sukendar (1999: 18) mencoba menguraikan tentang kehidupan perdagangan dan pelayaran serta perahu atau kapal pada masa Hindu di daerah Lasem dan Tuban. Dikatakan bahwa

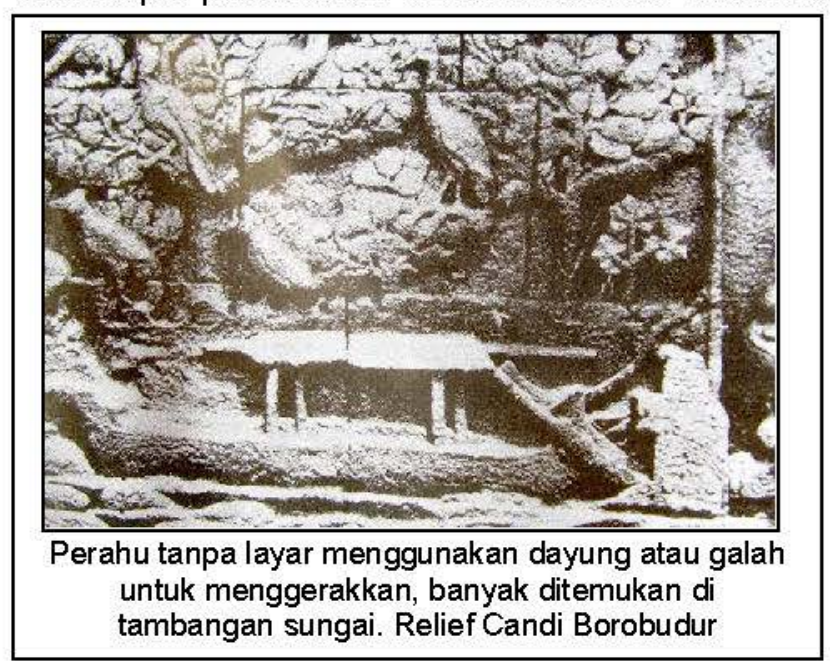
dari berita-berita Portugis abad ke-17 dan juga berita VOC kapal-kapal dari Jawa melakukan perdagangan di seluruh Nusantara bahkan hingga Benua Asia Tenggara dan Kepulauan Filipina. Pusat perdagangan yang terpenting pada waktu itu adalah Tuban, Gresik, Jepara termasuk juga Sedayu. Di tempat-tempat itu terdapat lebih dari seribu perahu. Warung- 
warung sementara dibuat di tepi pantai untuk menjual dagangan. Berdasarkan bukti tertulis tersebut, tidak dapat diragukan lagi kiprah dan peranan penduduk Jawa dalam dunia bahari tentunya sudah berlangsung lama, bahkan mungkin sejak sebelum masuknya pengaruh kebudayaan Hindu-Buddha dari India ke Indonesia.

Menurut Sukendar (1999: 65), perahu tidak hanya digunakan untuk perdagangan, tetapi juga digunakan oleh para raja untuk bepergian ke suatu tempat. Kegunaan perahu itu disebutkan dalam beberapa sumber baik berupa prasasti, kitab sastra, kitab keagamaan, maupun pada relief candi. Dari hasil pembacaan beberapa prasasti di Indonesia, diketahui adanya perjalanan-perjalanan yang dilakukan oleh raja untuk mengunjungi suatu tempat, selain pengiriman pasukan (bala tentara) dan aktivitas perdagangan. Demikian pula karya tulis Jaman Majapahit, seperti Nagarakretagama dan Pararaton, dapat juga dipakai sebagai sumber untuk mengetahui bagaimana aktivitas kelautan telah dilaksanakan oleh seorang raja

Lalu lintas pelayaran di Jawa Timur pada masa itu sudah ramai dengan berbagai jenis perahu besar maupun kecil. Schrieke (1957: 21) menyebutkan bahwa perahu-perahu yang banyak berlabuh di pelabuhan Jaratan di Jawa Timur merupakan perahu-perahu jung, yaitu perahu kayu berukuran besar tanpa cadik yang mampu mengangkut barang sampai ratusan ton. Bukan tidak mungkin bahwa perahu-perahu jung ukuran kecil, sedang dan besar telah dibuat oleh bangsa Indonesia sendiri (orang-orang Majapahit). Hal ini dapat dimengerti karena pada masa Majapahit teknologi pembuatan perahu telah begitu maju (Sukendar, 1999: 76). Perahu dibuat dari bahan kayu dengan teknik penyambungan yang tidak menggunakan paku, tetapi memakai pasak (pantek) dari bahan kayu.

\section{DATA ETNOGRAFI PEMBUATAN PERAHU DI JAWA UTARA}

Sungai Bengawan Solo bermuara di daerah Kabupaten Gresik. Pada Masa Klasik diduga sungai tersebut dapat dilayari dari pesisir sampai ke daerah pedalaman, meskipun pada saat ini tidak dapat dilayari karena mengalami pendangkalan. Selain itu, sudah banyak sarana jalan darat yang dapat menjadi sarana perhubungan antarwilayah di daerah aliran sungai tersebut, sehingga sungai tidak banyak lagi dimanfaatkan untuk transportasi. Ketika itu, perahu yang digunakan untuk menyusuri Bengawan Solo kemungkinan adalah perahu berjenis kecil dan tidak menggunakan layar. Perahu digerakkan dengan dayung dan galah dari bambu untuk mendorongnya. Sepanjang sungai tersebut kini masih banyak dijumpai adanya tambangan tradisional, seperti di daerah Mojopura, Kecamatan Bungah, Kabupaten Gresik. Istilah tambangan berarti tempat penyeberangan dari satu tepi ke tepi sungai lainnya.

Gresik di masa lalu merupakan salah satu bandar yang ramai. Hal itu dikaitkan dengan nisan Fatimah binti Maimun bin Hibatullah di Situs 
Leran yang berangka tahun $475 \mathrm{H}(1082 \mathrm{M})$. Penelitian yang dilakukan oleh Pusat Penelitian Arkeologi Nasional, menunjukkan bahwa wilayah sekitar Situs Leran mengandung sisa kehidupan yang menunjukkan keberadaan bandar di tempat ini pada abad X - XIV M. Banyak temuan keramik di daerah ini berasal dari abad XI- XIV M dan umumnya berasal dari Cina. Selain itu, ditemukan pula sisa bangkai perahu yang dibangun dengan menggunakan pasak kayu di kedalaman 2.5 meter (Tim Puslit Arkenas, 1994).

Penduduk yang tinggal di pesisir utara Jawa, khususnya yang tinggal dekat dengan muara sungai-sungai besar, biasanya memiliki profesi pekerjaan sesuai dengan kemampuannya masing-masing. Profesi yang banyak dipilih waktu itu antara lain adalah nelayan dan pembuat atau tukang memperbaiki perahu. Membuat perahu memerlukan keahlian khusus, biasanya mereka juga melakukan pekerjaan sebagai tukang kayu, karena perahu menggunakan bahan dari kayu. Profesi sebagai orang yang memiliki kepandaian/ keahlian dalam suatu pekerjaan pertukangan, dalam masyarakat Jawa kuna disebut undhagi. Apakah tukang membuat perahu termasuk dalam istilah tersebut? Edi Sedyawati dalam Koestara (1997: 71) menjelaskan bahwa Prasasti Hantang yang berhuruf dan berbahasa Jawa kuna, berangka tahun $1135 \mathrm{M}$ dan dikeluarkan oleh raja Jayabhaya, dikenal adanya profesi baru yakni undhagi lancan. Mereka sebagai ahli membuat perahu yang termasuk golongan yang digaji raja. Berdasarkan penafsiran prasasti, istilah undhagi lancan digunakan untuk tukang pembuat perahu. Para tukang diduga tinggal di pinggiran sungai untuk memudahkan akses selama proses pembuatan dan pemindahan perahu yang sudah jadi dari darat ke sungai. Namun, istilah tersebut sudah tidak dikenal lagi oleh nelayan masa kini. Saat ini pembuat perahu disebut baitho dan pembuat perahu di pinggiran sungai di daerah pedalaman tidak dapat ditemukan lagi.

Salah satu aspek menarik dari teknologi pembuatan perahu adalah cara menyambung papan dengan pantek atau pasak. Teknologi itu masih dapat dilihat pada pembuatan perahu tradisional di beberapa daerah, seperti Madura, Gresik, Tuban dan Karimunjawa (Kabupaten Jepara). Penggunaan pantek sebenarnya terkait masalah teknis dan kekuatan sambungan. Ketika mereka merangkai atau menyambung bagian per bagian perahu digunakan pantek yang bersifat sementara, khususnya digunakan untuk penyetelan. Setelah semuanya dirasakan pas, maka pantek tersebut dilepas kemudian diganti yang permanen. Setelah dipasang dengan dipukul dan ditekan dengan kayu, kemudian bagian samping kanan dan kiri pantek dibuat lubang menyilang (berlawanan arah) dengan pantek utama. Lubang tersebut kemudian disisipi dengan pantek berukuran lebih kecil yang berfungsi sebagai pengancing, sehingga tidak dapat bergerak atau lepas.

Perahu tradisional yang dibuat tanpa paku oleh tukang baito (pembuat perahu) pada umumnya berukuran kecil dan hanya dapat mengangkut dua orang. Biasanya dipakai untuk memasang dan mengangkat jaring ikan di daerah pantai. Namun, di masa lalu teknologi 
tersebut diyakini telah digunakan dalam pembuatan perahu-perahu berukuran sedang maupun besar. Berdasarkan beberapa bukti perahu kuna yang ditemukan dari beberapa tempat di Indonesia dan Asia Tenggara, teknologi pasak atau pantek kayu juga telah digunakan dalam pembuatan perahu yang berukuran besar.

Relief Candi Borobudur menggambarkan perahu menggunakan tiga layar utama dan bercadik yang berfungsi sebagai alat keseimbangan. Berdasarkan data etnografis perahu yang sebesar itu, mirip dengan perahu pinisi. Dengan ukuran sama kapal-kapal itu mampu mengangkut hingga ratusan ton barang dagangan dan rempah-rempah. Selain berukuran besar, kapal seperti itu tentunya bisa mengarungi samudra dengan gelombang tinggi dan arus yang kuat.

Perahu dengan menggunakan layar tunggal dan berukuran lebih kecil digunakan untuk berlayar antarpulau sekitar Pulau Jawa, Kalimantan, Sumatra, Sulawesi dan pulau-pulau sekitarnya. Perahu tanpa layar, berukuran relatif kecil, untuk menggerakkan mengandalkan dayung dan galah bambu dengan tenaga manusia. Biasanya digunakan untuk menyusuri sungai mengangkut orang atau barang, dari kapal apabila kapal tidak bisa merapat ke pantai. Perahu dengan jenis tanpa layar, banyak digunakan oleh tukang satang atau tambangan, untuk menyeberangkan orang atau barang.

Dugaan adanya cukup banyak bandar di pantai utara Jawa pada abad X - XIV M masih belum diketahui tepat lokasinya, karena bukti-bukti arkeologis masih perlu dikumpulkan. Namun, adanya desa-desa nelayan yang tersebar di wilayah di daerah pantai utara Jawa menyiratkan adanya kesinambungan budaya. Hal ini terlihat khususnya pada aspek kehidupan nelayan dan pembuatan perahu tradisional. Kini, di sepanjang pantai utara, sampai daerah perbatasan kabupaten Tuban masih dapat ditemukan desadesa nelayan. Juga di sekitar muara Bengawan Solo di sebelah barat Kabupaten Gresik, terdapat desa nelayan, antara lain Desa Campurrejo dan Ujung Pangkah. Penduduk di kedua desa secara turun temurun masih melakukan pekerjaan sebagai nelayan dan pembuat perahu. Mereka masih mewarisi cara penyambungan papan kayu menggunakan pasak/pantek dari bahan kayu. Namun, sesuai perkembangan dan permintaan pemesan perahu, pasak kini digantikan dengan paku besi agar lebih murah. Profesi mayoritas penduduk adalah nelayan dan pembuat perahu. Dua jenis bidang pekerjaan yang berbeda dalam keseharian mereka. Tukang perahu disebut tukang baitho sebuah pekerjaan yang memerlukan keakuratan. Selain membuat perahu, kadang mereka juga memperbaiki perahu yang rusak akibat benturan dengan karang, kayu atau gelombang. Untuk perbaikan diperlukan keterampilan untuk menentukan komponen apa yang harus diganti, jenis bahan, serta teknik penyambungannya. Sementara itu sebagai nelayan, mereka berlayar mencari ikan sampai berhari-hari dengan menggunakan perahu buatan desanya sendiri. Pada saat ini hampir semua perahu nelayan telah menggunakan mesin tempel sebagai tenaga utama, sehingga aktivitas mereka tidak tergantung pada alam (angin). 
Desa Campurrejo dan Ujung Pangkah terletak di dekat muara sungai dan dikenal sebagai penghasil ikan laut. Menurut nelayan, banyaknya ikan di perairan tersebut disebabkan oleh terumbu karang yang sangat luas di kedalaman sekitar 40 meter. Karena itu, jaring yang digunakan sering menyangkut di kedalaman tersebut. Terumbu karang merupakan salah satu tempat berkembang biaknya berbagai jenis florafauna laut yang disukai ikan sebagai tempat mencari makan dan bersarang. Para nelayan menggunakan perahu berlayar tunggal untuk menangkap ikan, seringkali dilengkapi dengan mesin tempel. Ketika masih menggunakan layar, komunikasi antara pemilik kapal dengan anak buah kapal dilakukan dengan memakai istilah yang menarik dan sering diucapkan, terutama untuk memberikan perintah atau aba-aba. Menurut mereka, istilah yang digunakan tersebut sudah ada sejak nenek moyang yang pada intinya mudah, singkat, jelas, dan mudah dipahami. Sekurangnya ada duapuluh lima istilah, tetapi sesuai dengan perkembangan jaman, semakin jarang penggunaan layar, bersamaan waktu itulah istilah-istilah tersebut kini hanya sekitar delapan yang masih digunakan. Beberapa istilah yang tidak dikenal berkaian dengan navigasi, sedangkan nelayan pada saat ini memilih menggunakan kompas dan Geographic Position System (GPS) dan "sounding sonar". Hal tersebut sangat memprihatinkan dan dikuatirkan informasi yang dapat digali dari istilah tersebut akan hilang. Padahal istilah tersebut dapat diacu sebagai bahan etnografis yang bermanfaat dalam penelitian etnoarkeologi maritim, sebagai bahan analogi. Beberapa istilah tersebut sebagai berikut.
- Layare dibarit
= layar supaya ditarik, disiapkan tetapi dalam posisi masih terikat dan melepaskan beberapa simpul- simpul tali untuk persiapan melepas (mengembangkan) layar.

- Jumpat = Menarik layar supaya mengembang, dilakukan pada saat perahu sudah berada di atas air yang tenang dan mendorong perahu ke tengah laut.

- Rebah = Melakukan penggulungan layar untuk berhenti dan melepas jaring dengan mengikuti arus. Istilah ini digunakan juga ketika perahu berada di pantai untuk parkir.

- Iiran

= Angin yang datang dari arah buritan, dalam hal ini layar supaya dapat berkembang dengan sempurna dan mendorong perahu ke depan.

- Ngepal = Istilah yang digunakan untuk berlayar mengikuti arah angin.

- Branjang = Rumah-rumahan di tengah laut untuk mencari ikan dengan memasang jaring.

- Tedho = Suatu tanda yang diberikan, ketika di tengahtengah laut tiba-tiba angin tidak bertiup,karena itu 
mereka bersiap menggunakan dayung untuk menjaga keseimbangan dengan arah arus.

= Membalik arah layar, ketika arah angin berubah agar mendapat daya dorong yang lebih kuat. Contoh; angin berhembus dari timur laut, tiba-tiba berubah dari arah tenggara akan mengurangi laju perahu karena itu layar posisinya harus dibalik dari cara mengikat dan pengendaliannya.

Dari delapan jenis istilah atau kata tadi, semuanya menggunakan bahasa Jawa, tetapi tidak digunakan dalam percakapan sehari-hari, hanya diucapkan dalam komunikasi kepada sesama nelayan ketika sedang berlayar mencari ikan. Sayang penggunaannya kini semakin jarang terdengar, karena mengandalkan sehingga peran layar semakin kurang berfungsi. Bersamaan dengan itu, sangat mungkin di masa mendatang bahasa

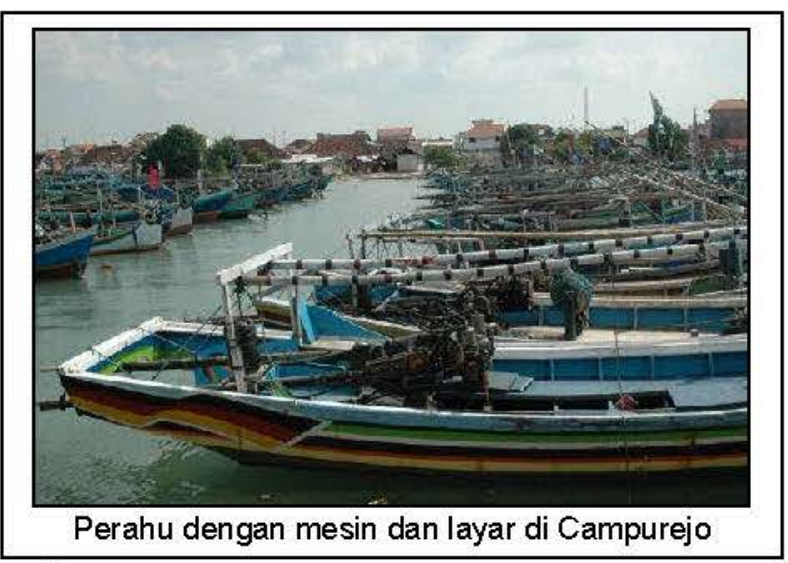
komunikasi tersebut akan musnah.

\section{PENUTUP}

Anugerah terbesar bagi Indonesia sebagai negara kepulauan (archipelagic state) atau bahari (maritime) adalah letaknya yang sangat strategis dalam konfigurasi peta bahari dunia. Kepulauan ini berupa untaian pulau-pulau yang sambung menyambung dan merentang di antara Benua Asia dan Australia serta melintang di antara Samudra Hindia dan Pasifik (Pramono, 2008: 1). Anugerah itu secara arkeologis sudah dapat dibuktikan sejak masa kejayaan Kerajaan Sriwijaya di Sumatera dan Majapahit di Jawa. Bukti-bukti arkeologis berupa prasasti dan gambar perahu pada dinding Candi Borobudur, menjelaskan bahwa nenek moyang mampu membuat perahu untuk mengarungi samudra luas dan menguasai Nusantara.

Beberapa gambar pahatan pada relief candi dari abad VIII $\mathrm{M}$ dan sumber-sumber dalam prasasti abad ke X - XIV M, menyebut tentang perahu dan jenisnya. Sumber ini juga memberikan gambaran bahwa ukuran besar dan kecilnya perahu membedakan fungsinya masing-masing. Selain itu, teknologi pembuatan khususnya cara penyambungan komponen perahu menggunakan pasak pantek dari bahan kayu. Sementara itu, data 
etnografis yang masih ada pada masyarakat nelayan di Campurrejo dan Ujung Pangkah tentunya dapat dimanfaatkan sebagai bahan analogi. Dalam konteks ini cara pembuatan perahu dengan bermacam ukuran, seperti teknik penyambungan, penggunaan bahan dan pengangkatan (peluncuran) dari tempat pembuatan ke laut merupakan informasi yang menarik. Memang persyaratan sebagai bahan analogi secara ideal agak sulit ditemukan dalam masyarakat tradisional di Jawa Timur. Analogi dengan rentang waktu selama lebih dari tujuh ratus tahun (700) mungkin terlalu lama. Selama itu, tentu telah terjadi perubahan dan penemuan teknologi baru, sehingga mempengaruhi perilaku masyarakat nelayan. Teknologi merupakan salah satu penyebab lemahnya konservativitas budaya nelayan, sebagai contoh dari penggunaan layar digantikan oleh mesin. Namun demikian, dari beberapa unsur lain masih dapat dilacak dan diketahui tentang tatacara dan teknologi pembuatan perahu seperti, bentuk, jenis, bahan dan teknik penyambungan.

Dalam hal ini, artefak mampu menyumbangkan bukti-bukti kejayaan bangsa, sehingga dapat dipakai sebagai jatidiri. Data itu dapat pula mengungkap peradaban dan pembangunan Indonesia telah dirintis oleh nenek moyang sejak dahulu. Kemauan, tekad dan semangat mereka patut dijadikan acuan untuk membangun semangat generasi muda Indonesia, agar mencintai tanah air dengan menanamkan semangat nasionalisme. Oleh karena itu, hal penting yang harus dilakukan oleh bangsa ini, adalah melakukan pelestarian warisan budaya, baik yang tangible berupa bangunan monumental, maupun budaya intangible berupa nilai-nilai, aturan yang ada dalam kehidupan masyarakat nelayan. Cara itulah yang dapat menjaga dan melestarikan 'warisan', sehingga di desa-desa nelayan, khususnya di Jawa Timur, kita masih dapat mendengarkan yang diucapkan nelayan, seperti ..."ayo dibarit, ngepal, tadar..." yang mungkin juga pernah diucapkan nenek moyang pada Masa Jawa Kuna, sebagai salah satu bukti kejayaan negeri bahari...

\section{KEPUSTAKAAN}

Brandes, JLA - Krom, 1913, Oud-Javaansche Oorkonden, VBG LX

Koestara, Lucas Partanda,1997. Pelautkah Orang Jawa? Kebudayaan, Departemen Pendidikan dan Kebudayaan, Jakarta.

Nastiti, Titi Surti, 2003. Pasar di Jawa Masa Mataram Kuna Abab VIII - XI Masehi. PT. Dunia Pustaka Jaya. Jakarta.

Pigeuad, TG Th, 1969. Java In The 14th Century. A Study In Cultural History s' Gravenhage: Martinus Nijhoff. 
Pramono, Djoko, 2005. Budaya Bahari. PT Gramedia Pustaka Utama. Jakarta.

Setianingsih, Rita Margaretha, 1993 Perahu Dalam Beberapa Prasasti Indonesia. Berkala Arkeologi. Tahun XIII (1). Balai Arkeologi Yogyakarta. Yogyakarta.

Soekarto K Atmodjo, M.M. 1979, Struktur Masyarakat Jawa Kuna Pada Jaman Mataram Hindu Dan Majapahit. Pusat Penelitian dan Studi Pedesaan. UGM. Yogyakarta.

Stutterhem, WF., 1934. Een vrtj over zet veer te Wanagiri in 903 AD, TBG 74. hal. $269-295$. 1938. JBG, hal $121-122$.

Sukendar, Haris, 1999. Perahu Tradisional Nusantara (Tinjauan Melalui Bentuk dan Fungsi). Proyek Pengembangan Media Kebudayaan Direktorat Jenderal Kebudayaan, Departemen Pendidikan dan Kebudayaan. Jakarta.

Sutjipto Wirjosoeparto, 1958. Apa Sebabnya Kediri Muncul Dalam Sejarah, Laporan KIPN I. Lembaga IImu Pengetahuan Indonesia. Jakarta

Tjahjono, Baskoro Daru, 2008. Candi Losari Sebuah Kompleks Candi Hindu di Kawasan Sekitar Borobudur. Yayasan Tahija dengan Balai Arkeologi Yogyakarta. 